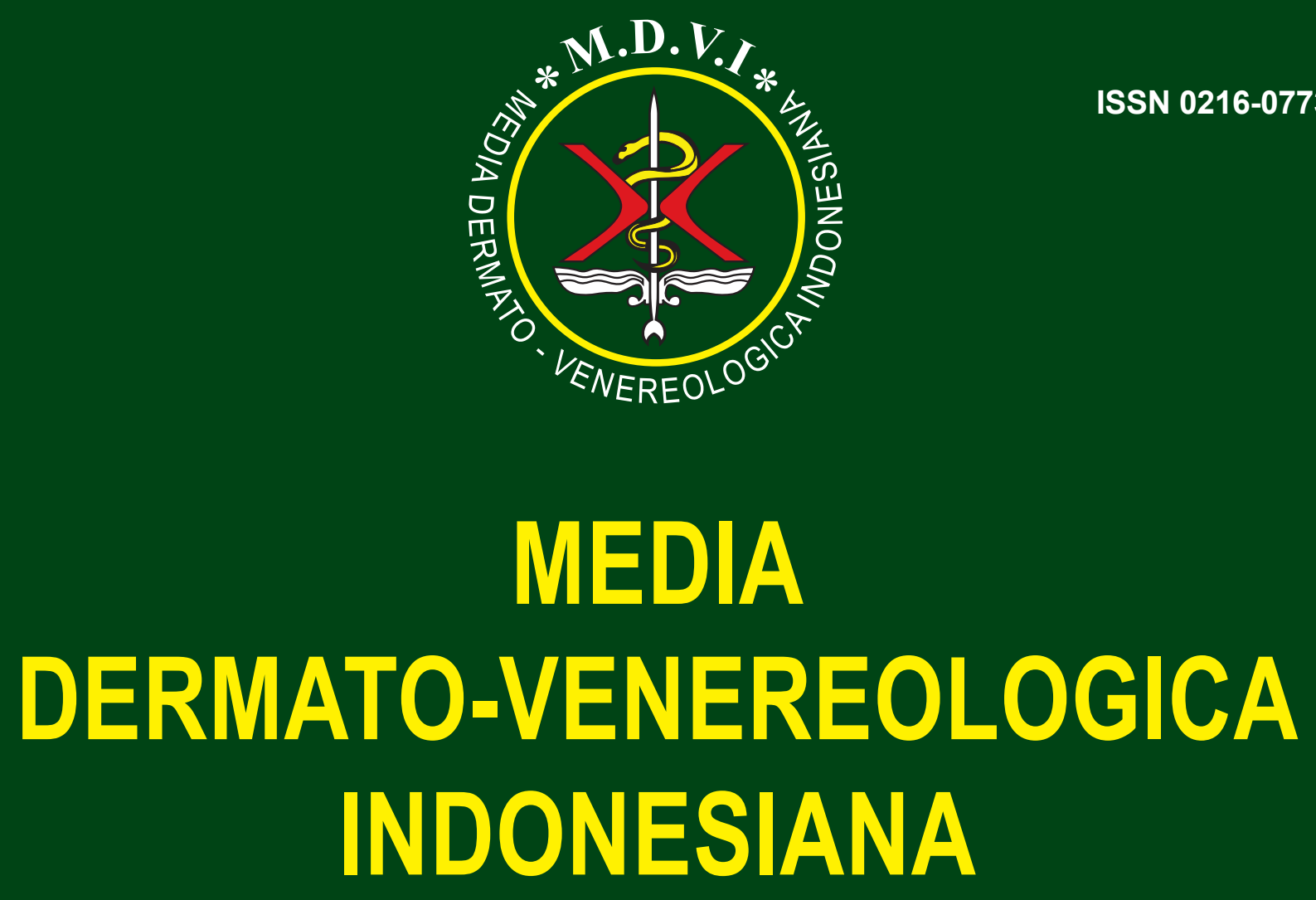

Editorial : Trias epidemiologis : Pendekatan memahami orkestra sistem imunologi kulit

Uji klinis sampo formulasi khusus pada pasien ketombe dan dermatitis seboroik ringan pada skalp

Tingkat pengetahuan dan sikap pekerja binatu terhadap dermatitis kontak

Korelasi antara kadar superoksida dismutase dengan malondialdehid pada jaringan keratosis seboroik

Psoriasis vulgaris berat diterapi mikofenolat mofetil: tantangan dalam pengobatan

Terapi dapson pada pemfigoid bulosa

Modern wound dressing pada ulkus trofik pasien kusta tipe lepromatosa

Peningkatan enzim transaminase pada kusta

Korelasi gambaran histopatologi, teknik biopsi dan manifestasi klinis vaskulitis leukositoklastik kutan

Peran mikrobiom pada infeksi menular seksual

Melasma dalam sudut pandang genetik 


\title{
KORELASI ANTARA KADAR SUPEROKSIDA DISMUTASE DENGAN MALONDIALDEHID PADA JARINGAN KERATOSIS SEBOROIK
}

\author{
Arif Widiatmoko, Tantari SHW, Yusuf Ardian
}

Departemen Ilmu Kesehatan Kulit dan Kelamin

FK Universitas Brawijaya/RSUD dr. Saiful Anwar, Malang

\begin{abstract}
ABSTRAK
Keratosis seboroik (KS) merupakan tumor jinak epidermis dan sering dikeluhkan karena secara kosmetik mengganggu penampilan. Superoksida dismutase (SOD) merupakan salah satu antioksidan enzimatik intraseluler yang efektif mencegah stres oksidatif sebagai penyebab utama proses penuaan dan pembentukan lesi tumor keratosis seboroik. Malondialdehid (MDA) adalah senyawa dialdehida produk metabolit oksidasi membran sel oleh radikal bebas. Kadar antioksidan yang rendah biasanya disertai dengan peningkatan kadar MDA.Penelitian ini bertujuan untuk mengetahui korelasi kadar SOD dan kadar MDA jaringan pada pasien keratosis seboroik.

Desain penelitian ini adalah analitik observasional potong lintang. Subjek penelitian didapatkan dari Poliklinik Kulit dan Kelamin RSUD dr. Saiful Anwar Malang secara consecutive sampling. Semua proses diagnosis, terapi pengangkatan lesi, serta pemeriksaan kadar SOD dan MDA jaringan keratosis seboroik dilakukan terhadap masing-masing subjek penelitian. Pemeriksaan SOD dan MDA jaringan menggunakan cara enzyme-link immunosorbent assay (ELISA) Bioassay. Uji normalitas data menggunakan uji KolmogorovSmirnov. Uji korelasi menggunakan uji Pearson. Analisis statistik menggunakan program Statistical Package for Social Sciences (SPSS) versi 15.

Subjek penelitian yang didapatkan sebanyak 20 pasien. Rerata kadar SOD jaringan sebesar 0,7665 $\mu M / L$ dan rerata kadar MDA jaringan sebesar 0,6727 $\mu M / L$. Koefisien korelasi antara kadar SOD jaringan dengan kadar MDA jaringan sebesar -0,447 dengan nilai $p=0,048$. Penelitian ini menunjukkan bahwa semakin rendah kadar SOD akan semakin tinggi kadar MDA pada jaringan keratosis seboroik.
\end{abstract}

Kata kunci: keratosis seboroik, SOD, MDA

\section{CORRELATION BETWEEN SUPEROXIDE DISMUTASE WITH MALONDIALDEHYDE LEVEL IN SEBORRHEIC KERATOSIS TISSUE}

Korespondensi:

Jl. Jaksa Agung Suprapto no 2 Malang

Telp/Fax: +62341-340991,

HP: +628123388015

E-mail: arif fk@ub.ac.id

\begin{abstract}
Seborrheic keratoses (SKs) is the most common benign epidermal skin tumor, which often becomes patient concern because of its cosmetical inconvenience. Superoxide dismutase (SOD) is one of the most effective intracellular enzymatic antioxidants to prevent oxidative stress as the main culprit in the aging process and tumor formation of in seborrheic keratosis. Malondialdehyde (MDA) is a dialdehydes cell compound as a product of metabolite components produced by free radicals. Low antioxidant level usually accompanied with increasing levels of MDA. This study determines the correlation between tissue levels of SOD and MDA in seborrheic keratosis.

This was across-sectional observational analytic study. Subjects were recruited from Dermatovenereology Outpatient Clinic in dr. Saiful Anwar Hospital Malang with consecutive sampling method. The data collected from subjects who meet the research admission criteria. All diagnostic process, lesion removal and examination of SOD and MDA tissue level were performed to each subject. Tissue SOD and MDA level measured by enzyme-link immunosorbent assay (ELISA) Bioassay. Normality test was measured by Kolmogorov-Smirnov test. Correlation test was measured by Pearson test. Statistic analysis was performed by Statistical Package for Social Sciences (SPSS) version 15.

The subject collected in this study was 20 patients. The average tissue levels of SOD were $0.7665 \mathrm{U} /$ $m L$ and MDA were $0.6727 \mu M$. The correlation coefficient between tissue levels of SOD and MDA was -0.447 with significant value $p=0.048(p<0.05)$. This study concluded that there was significant negative correlation between SOD and MDA tissue levels in seborrheic keratosis which means the lower SOD level, the higher MDA level.
\end{abstract}

Key words: seborrheic keratosis, SOD, MDA 


\section{PENDAHULUAN}

Keratosis seboroik (KS) merupakan tumor jinak di epidermis dan sering dikeluhkan karena memengaruhi penampilan. KS sering timbul pada usia pertengahan, walaupun dapat muncul lebih cepat atau pada dewasa muda. Sebanyak $50-100 \%$ didapatkan pada usia di atas 50 tahun. Insidens keratosis seboroik pada berbagai penelitian bervariasi antara $24,2 \%$ sampai $74,5 \%$. Smith dkk. melaporkan prevalensi KS sebesar $88 \% .^{2}$ Angka kejadian keratosis seboroik di Indonesia tidak diketahui. Data poliklinik Kulit dan Kelamin Rumah Sakit dr. Saiful Anwar (RSSA) Malang tahun 2014 mendapatkan 98 kasus $(0,79 \%)$ dari seluruh kunjungan dan tahun 2015 sebanyak 68 kasus $(1,01 \%)$ dari seluruh kunjungan.

Radikal bebas diketahui merupakan salah satu teori penuaan. Radikal bebas di dalam tubuh paling banyak berasal dari oksigen yang disebut reactive oxygen species (ROS) yang terbentuk akibat stres oksidatif dan berperan sangat penting dalam proses penuaan. ROS dapat menjadi mediator dasar terjadinya kerusakan struktur sel, termasuk lipid dan membran protein, serta asam nukleat. Kerusakan tersebut dikenal sebagai stres oksidatif. ${ }^{3}$

Beberapa penelitian menjelaskan pajanan radiasi sinar ultraviolet pada kulit manusia yang menyebabkan oksidasi biomolekul seluler dapat dicegah dengan pemberian antioksidan lebih dahulu untuk menanggulangi kekurangan antioksidan endogen. Pada kulit terdapat antioksidan enzimatik endogen mayor dan antioksidan nonenzimatik yang bersifat protektif, akan tetapi mekanisme perlindungan kerusakan selsel terhadap kerusakan oksidatif yang disebabkan oleh radiasi sinar ultraviolet belum jelas. ${ }^{4}$ Superoksida dismutase (SOD) merupakan salah satu antioksidan enzimatik intraseluler yang paling efektif dan mengkatalisasi konversi anion superoksida menjadi dioksigen dan hidrogen peroksidase. Penelitian yang dilakukan oleh Robins dkk. serta Treiber dkk. menunjukkan perubahaan konsentrasi dan aktivitas antioksidan pada kulit yang mengalami penuaan atau tumor., ${ }^{5,6}$ Malondialdehid (MDA) adalah senyawa dialdehida yang merupakan produk hiperoksidasi lipid dalam tubuh dan merupakan indikator lipid peroksidasi. MDA merupakan metabolit komponen sel yang dihasilkan oleh radikal bebas. Konsentrasi MDA yang tinggi menunjukkan proses oksidasi terjadi dalam membran sel. Status antioksidan yang tinggi biasanya diikuti oleh penurunan kadar MDA. ${ }^{7}$

Beberapa penelitian menunjukkan peningkatan kadar MDA pada tumor jinak maupun ganas. ${ }^{8-10}$ Sejauh pengetahuan penulis belum ada penelitian kadar MDA dan SOD pada keratosis seboroik yang merupakan tumor jinak kulit. Penelitian ini bertujuan untuk mengetahui korelasi kadar SOD dan kadar MDA jaringan keratosis seboroik.

\section{METODE}

Desain penelitian ini adalah potong lintang analitik. Subjek penelitian adalah pasien keratosis seboroik laki-laki maupun perempuan berusia 25 tahun atau lebih dan bersedia menjadi subjek penelitian serta menandatangani lembar persetujuan medis dan penelitian. Kriteria penolakan subjek penelitian, antara lain pasien penyakit autoimun dan keganasan kulit, pasien diabetes mellitus tipe 2 lebih dari 10 tahun dengan kadar gula darah tidak terkontrol, menggunakan antioksidan topikal 3 hari sebelum penelitian, mengonsumsi antioksidan sistemik secara rutin dan terus menerus selama 28 hari terakhir sebelum penelitian, menggunakan bahan topikal yang mengandung 5-fluorourasil, tretinoin, adapalen, asam glikolat, asam alfa hidroksi dan terapi peeling kimiawi pada lesi KS atau kulit di sekitar lesi KS dalam 7 hari terakhir sebelum penelitian.

Penelitian dilakukan di Poliklinik Kulit dan Kelamin RSUD dr. Saiful Anwar (RSSA) Malang sejak bulan September hingga Oktober 2016. Besar sampel pada penelitian ini dihitung berdasarkan rumus besar sampel tunggal untuk koefisien korelasi dan didapatkan jumlah sampel minimal sebanyak 17 orang, yang kemudian dibulatkan menjadi 20 subjek. Diagnosis KS ditegakkan berdasarkan anamnesis dan pemeriksaan dermatologis oleh 3 orang pemeriksa. Proses pengangkatan tumor dan pengambilan sampel jaringan untuk pemeriksaan kadar SOD dan MDA dilakukan oleh dokter yang terlatih di ruang tindakan poliklinik Kulit dan Kelamin RSSA. Pemeriksaan kadar SOD dan MDA jaringan dilakukan dengan metode enzyme-link imunnosorbent assay (ELISA) Bioassay di laboratorium Fisiologi Fakultas Kedokteran Universitas Brawijaya (FKUB).

Uji normalitas dilakukan terhadap data kadar SOD dan MDA menggunakan uji Kolmogorov-Smirnov. Uji korelasi menggunakan uji korelasi Pearson dengan alternatif uji Spearman. Uji statistik menggunakan program Stastical Package for Social Sciences (SPSS) versi $15 .{ }^{11}$

\section{HASIL}

\section{Karakteristik subjek penelitian}

Subjek yang pada penelitian ini adalah 20 pasien keratosis seboroik dengan rentang usia antara 28-83 tahun. Rata-rata usia subjek penelitian ini adalah 50,95 (simpang baku 15,79) tahun. Subjek penelitian ini banyak didapatkan pada rentang usia antara 26-35 tahun (25\%) dan usia di atas 65 tahun (25\%). Tidak terdapat perbedaan bermakna dalam jumlah subjek berdasarkan kelompok usia $(p>0,05)$. Jenis kelamin terbanyak adalah perempuan, sebanyak 15 orang $(75 \%)$. Terdapat perbedaan yang bermakna antara jumlah subjek berdasarkan jenis kelamin $(p<0,05)$. Subjek dengan penyakit sistemik didapatkan sebanyak 4 pasien (20\%), antara lain dengan diabetes mellitus, penyakit jantung koroner, dan penyakit 
jantung ekstra-sistole. Riwayat penggunaan antioksidan dalam bentuk suplemen oral maupun topikal didapatkan pada 12 subjek (Tabel 1).

Tabel 1. Data dasar subjek penelitian pasien keratosis seboroik periode September - Oktober 2016 di RSUD dr. Saiful Anwar Malang

\begin{tabular}{|c|c|c|c|c|}
\hline Karakteristik & Kategori & $\begin{array}{l}\text { Frekuensi } \\
(\mathrm{n}=20)\end{array}$ & Persentase (\%) & $\mathrm{p}$ \\
\hline & $26-35$ & 5 & 25 & \\
\hline \multirow{4}{*}{ Usia (tahun) } & $36-45$ & 4 & 20 & \\
\hline & $46-55$ & 2 & 10 & \\
\hline & $56-65$ & 4 & 20 & 0,827 \\
\hline & $>65$ & 5 & 25 & \\
\hline \multirow[t]{2}{*}{ Jenis Kelamin } & Laki-laki & 5 & 25 & \\
\hline & Perempuan & 15 & 75 & 0,025 \\
\hline \multirow[t]{2}{*}{ Penyakit sistemik yg menyertai } & Ada & 4 & 20 & \\
\hline & Tidak ada & 20 & 80 & 0,007 \\
\hline \multirow[t]{2}{*}{ Penggunaan antioksidan } & Ada & 12 & 60 & \\
\hline & Tidak ada & 8 & 40 & 0,371 \\
\hline \multirow[t]{5}{*}{ Lokasi lesi KS } & Leher & 5 & 25 & 0,001 \\
\hline & Wajah & 1 & 5 & \\
\hline & Wajah, leher & 11 & 55 & \\
\hline & Wajah, leher, dada & 2 & 10 & \\
\hline & Tungkai bawah d/s & 1 & 5 & \\
\hline
\end{tabular}

$\mathrm{P}<0,05$ : terdapat perbedaan signifikan berdasar Chi-square

Hasil pemeriksaan kadar SOD dan MDA jaringan KS

Dari 20 subjek penelitian didapatkan kadar terendah SOD jaringan KS 0,132 U/mL dan tertinggi 1,092 U/mL. Rerata kadar SOD jaringan KS adalah $0,7665 \mathrm{U} / \mathrm{mL}$ (simpang baku 0,34 ). Kadar terendah MDA jaringan KS $0,528 \mu \mathrm{M}$ dan kadar tertinggi $0,884 \mu \mathrm{M}$. Rerata kadar MDA jaringan KS adalah $0,6727 \mu \mathrm{M}$ (simpang baku 0,11).

Uji distribusi data menggunakan uji Kolmogorov-Smirnov terhadap kadar SOD menunjukkan nilai $\mathrm{p}=0,065$ sedangkan uji terhadap kadar MDA menunjukkan nilai=0,672. Hasil ini menunjukkan tidak adanya perbedaan yang bermakna $(\mathrm{p}>0,05)$ sehingga dapat disimpulkan bahwa kadar SOD dan MDA jaringan keratosis seboroik pada penelitian ini berdistribusi normal. Uji korelasi Pearson dapat dilakukan karena asumsi kenormalan distribusi data telah terpenuhi. Tabel 2 menunjukkan rerata kadar SOD dan MDA jaringan KS berdasarkan morfologi lesi KS serta lokasi lesi tidak terdapat perbedaan yang bermakna $(p>0,05)$.

Tabel 2. Perbedaan Rerata Kadar SOD dan MDA Jaringan KS Berdasarkan Morfologi dan Lokasi Lesi KS periode September - Oktober 2016 di RSUD dr. Saiful Anwar Malang

\begin{tabular}{|c|c|c|c|c|c|}
\hline Karakteristik & Jumlah & $\begin{array}{l}\text { Rerata kadar SOD (U/ } \\
\text { mL) (simpang baku) }\end{array}$ & $\mathrm{p}$ & $\begin{array}{l}\text { Rerata kadar MDA }(\mu \mathrm{M}) \\
(\text { simpang baku) }\end{array}$ & $\mathrm{p}$ \\
\hline \multicolumn{6}{|l|}{ Morfologi lesi KS } \\
\hline Common KS & 14 & $0,786(0,353)$ & \multirow{6}{*}{$* 0,750$} & $0,655(0,144)$ & \multirow{6}{*}{$* 0,469$} \\
\hline Flat type KS & 1 & 0,952 & & 0,821 & \\
\hline Pedunculated KS & 1 & 0,813 & & 0,724 & \\
\hline Common KS dan Flat type KS & 3 & $0,747(0,404)$ & & $0,643(0,085)$ & \\
\hline Common KS dan & & & & & \\
\hline Pedunculated KS & 1 & 0,312 & & 0,796 & \\
\hline \multicolumn{6}{|l|}{ Lokasi lesi KS } \\
\hline Leher & 2 & $0,559(0,358)$ & \multirow{5}{*}{$* 0,681$} & $0,765(0,058)$ & \multirow{5}{*}{$* 0,160$} \\
\hline Wajah & 4 & $0,845(0,367)$ & & $0,608(0,102)$ & \\
\hline Wajah, leher & 11 & $0,714(0,370)$ & & $0,684(0,108)$ & \\
\hline Wajah, leher, dada & 2 & $1,011(0,24)$ & & $0,570(0,033)$ & \\
\hline Tungkai bawah & 1 & 0,952 & & 0,821 & \\
\hline
\end{tabular}

$* \mathrm{p}<0.05$ : terdapat perbedaan signifikan berdasar One Way Anova

$* * \mathrm{p}<0.05$ : terdapat perbedaan signifikan berdasar Independent $t$-test 
Uji Pearson untuk mengetahui korelasi antara kadar SOD dengan MDA jaringan KS menunjukkan koefisien korelasi sebesar -0,447 dengan nilai kemaknaan 0,048. Hasil ini menunjukan adanya hubungan korelasi negatif antara kadar SOD dengan MDA jaringan KS. Dengan kata lain, jika kadar SOD jaringan KS mengalami kenaikan maka kadar MDA jaringan KS akan mengalami penurunan dan begitu juga sebaliknya apabila kadar SOD jaringan KS mengalami penurunan maka kadar MDA jaringan KS akan mengalami kenaikan. Berdasarkan keeratan, nilai koefisien korelasi rentang antara 0,41 sampai 0,7 termasuk korelasi yang memiliki keeratan kuat.

\section{DISKUSI}

Keratosis seboroik (KS) yang disebut juga sebagai seborrheic warts, basal cells papilomas atau senile keratoses merupakan jenis lesi kulit yang sangat sering dijumpai. Data epidemiologis kasus KS masih sangat jarang. Pada beberapa referensi disebutkan bahwa KS mulai muncul pada usia dekade kelima pada pasien di daerah beriklim bukan tropis, dan muncul lebih cepat di daerah beriklim tropis. ${ }^{12}$ Subjek penelitian ini ditemukan dalam rentang usia antara 28-83 tahun dengan rerata usia 50,95 tahun (simpang baku 15,79). Rentang usia subjek penelitian ini ditemukan paling banyak masuk dalam dekade kelima kehidupan yaitu sebanyak 11 pasien (55\%). Rentang usia ini lebih banyak bila dibandingkan rentang usia yang lain meskipun tidak berbeda bermakna secara statistik $(p=0,827)$.

Rerata kadar SOD jaringan KS terendah pada penelitian ini terdapat pada kelompok usia 26-35 tahun $(0,502 \mathrm{U} / \mathrm{mL})$ dan tertinggi pada kelompok usia 46-55 tahun $(0,994 \mathrm{U} / \mathrm{mL})$. Rerata kadar MDA jaringan KS terendah pada penelitian ini terdapat pada kelompok usia 56-65 tahun $(0,61 \mathrm{mM})$ dan tertinggi pada kelompok usia 26-35 tahun (0,7123 mM). Penelitian Nindyasari yang mengukur kadar serum MDA pada 50 pasien melasma dan 50 pasien kontrol didapatkan perbedaan rerata kadar MDA serum berdasarkan kelompok umur meskipun tidak bermakna $(p=0,394){ }^{7}$ Bertambahnya usia seseorang, diikuti dengan meningkatnya produksi radikal bebas sehingga sel tubuh akan mengalami degenerasi, dan sel bekerja tidak optimal yang berdampak pada rendahnya aktivitas enzim selular (SOD, katalase, dan glutation peroksidase) ${ }^{13}$. Banerjee pada tahun 2012 menyebutkan bahwa pada keratosis seboroik tidak terdapat predisposisi jenis kelamin, namun lebih sedikit pada jenis ras kulit hitam dibandingkan jenis ras kulit putih. ${ }^{14}$

Pada penelitian ini jumlah subjek dengan riwayat penggunaan antioksidan sebanyak 12 subjek $(60 \%)$ sedangkan 8 subjek (40\%) tidak menggunakan antioksidan. Rerata kadar SOD jaringan KS subjek penelitian yang menggunakan antioksidan 0,8619 U/m (simpang baku 0,3099) lebih tinggi dari kelompok subjek yang tidak menggunakan antioksidan 0,6234 U/mL (simpang baku 0,3527) meskipun secara statistik tidak berbeda bermakna $(p=0,238)$. Rerata kadar MDA jaringan KS subjek penelitian yang tidak menggunakan antioksidan 0,7092 mM (simpang baku 0,1306) lebih tinggi dari kelompok subjek yang menggunakan antioksidan 0,6484
$\mathrm{mM}$ (simpang baku 0,0929) meskipun tidak berbeda bermakna secara statistik $(\mathrm{p}=0,128)$.

Penggunaan antioksidan di kulit secara topikal dikombinasi dengan oral dapat meningkatkan kapasitas antioksidan di dalam tubuh karena keduanya bekerja secara sinergis. Pemberian antioksidan oral dapat mengurangi stres oksidatif, demikian pula pemberian antioksidan topikal mampu mencegah kerusakan kulit yang disebabkan oleh stres oksidatif. Penelitian Yaar dan Gilchrest menyatakan bahwa pemberian antioksidan topikal dan oral dapat mengurangi akumulasi peroksida pada kulit. ${ }^{15}$

Berdasarkan IMT didapatkan kelompok subjek yang terbanyak dalam kategori normal dan yang paling sedikit kategori obesitas, meskipun tidak berbeda bermakna secara statistik ( $\mathrm{p}=0,212)$. Rerata kadar tertinggi SOD KS jaringan pada kelompok subjek obesitas $(0,7993 \mathrm{U} / \mathrm{mL})$, sedangkan rerata kadar terendah SOD jaringan $\mathrm{KS}$ pada kategori overweight $(0,7491 \mathrm{U} / \mathrm{mL})$, rerata kadar terendah MDA jaringan KS pada kategori obesitas $(0,6534 \mathrm{mM})$ sedangkan rerata kadar tertinggi MDA jaringan KS pada kategori normal $(0,6959 \mathrm{mM})$, namun tidak berbeda bermakna secara statistik $(\mathrm{p}=0,978$ dan $\mathrm{p}=0,719)$. Hal tersebut berbeda dengan yang didapat oleh Winarsi dkk. bahwa rendahnya aktivitas SOD yang menandakan tingginya stres oksidatif, berkaitan dengan IMT lebih dari $31,89 .{ }^{13}$

Lokasi lesi KS pada penelitian ini terbanyak pada wajah dan leher (55\%). Hal tersebut sesuai dengan yang disebutkan oleh Banerjee bahwa lesi KS lebih sering terjadi pada daerah yang terpajan sinar matahari. ${ }^{14}$ Hafner dkk. juga menyebutkan bahwa mutasi FGFR3 pada KS berhubungan dengan usia dan lokasi lesi KS pada kepala dan leher $(\mathrm{p}<0,01) .{ }^{16}$

Korelasi antara kadar SOD jaringan KS dengan kadar MDA jaringan KS menunjukkan koefisien korelasi sebesar -0,447 dengan nilai p sebesar 0,048, sehingga dapat disimpulkan bahwa terdapat hubungan korelasi negatif yang bermakna $(\mathrm{p}<0,05)$ antara kadar SOD jaringan KS dengan kadar MDA jaringan KS. Dengan kata lain jika kadar SOD jaringan KS subjek mengalami kenaikan maka kadar MDA jaringan KS subjek akan menurun dan sebaliknya.

Pada penelitian ini didapatkan nilai koefisien korelasi $-0,447$ sehingga menurut pengelompokan keeratan korelasi Sujarweni termasuk korelasi dengan keeratan kuat. ${ }^{17}$ Belum terdapat penelitian yang menghubungkan perubahan kadar SOD dan kadar MDA pada pasien KS. Hasil penelitian ini sesuai dengan beberapa penelitian sebelumnya, didapatkan hubungan antara tumor jinak dengan peningkatan kadar MDA dan penurunan kadar SOD. Penelitian yang dilakukan oleh Ahmed menunjukkan peningkatan kadar MDA serum kelompok pasien tumor payudara dibandingkan kelompok kontrol. ${ }^{9}$

Radikal bebas bersifat destruktif, sangat reaktif dan mampu bereaksi dengan makromolekul sel, misalnya protein, lipid, karbohidrat atau DNA. Kerusakan oksidatif pada lemak tak jenuh dalam fosfolipid membran biologi yang disebut juga peroksidasi lipid menyebabkan kerusakan struktur membran dan hilangnya fungsi organel sel. Selanjutnya 
radikal peroksidasi lipid dapat juga menghilangkan satu atom hidrogen dari molekul lipid lainnya yang berdekatan untuk membentuk radikal karbon lainnya. Jika radikal lain tersebut bereaksi dengan oksigen maka reaksi peroksidasi lipid akan terus berlanjut. Pembentukan endoperoksida lipid pada polyunsaturated fatty acid yang mengandung sedikitnya tiga ikatan rangkap akan mendorong pembentukan MDA sebagai produk dari reaksi peroksidasi tersebut. MDA merupakan produk oksidasi asam lemak tidak jenuh oleh radikal bebas dan juga merupakan metabolit komponen sel yang dihasilkan oleh radikal bebas. Konsentrasi MDA yang tinggi menunjukkan adanya proses oksidasi dalam membran sel. ${ }^{18}$ Status antioksidan yang tinggi biasanya diikuti oleh penurunan kadar MDA. Superoksida dismutase yang merupakan antioksidan endogen tubuh jumlahnya akan menurun apabila terjadi peningkatan radikal bebas dalam proses stres oksidatif.,13

Etiopatogenesis KS belum sepenuhnya jelas dan diduga berkaitan dengan stres oksidatif. Sinar UVB bisa memicu pembentukan ROS yang menyebabkan tumbuhnya KS. Pemberiaan antioksidan bisa mengurangi proses pembentukan tumor pada keratosis seboroik. ${ }^{19}$ Faktor lingkungan yang dapat menyebabkan terbentuknya radikal bebas, antara lain pajanan sinar UV, polusi asap pabrik, emisi kendaraan bermotor, pengawet, kosmetik, obat dan lainnya akan dapat menyebabkan terbentuknya ROS dan terjadinya stres oksidatif. ${ }^{20}$

Pada penelitian ini terdapat beberapa kelemahan yang dapat menyebabkan terjadinya bias, antara lain faktor subjektivitas dalam penegakan diagnosis KS walaupun telah melibatkan 3 pemeriksa dengan kompetensi yang hampir sama. Stres oksidatif yang dinilai melalui pengukuran kadar SOD dan MDA sangat dipengaruhi oleh beberapa faktor lain, misalnya penuaan alamiah, faktor lingkungan, kelainan sistemik, konsumsi makanan dan minuman yang akan mempengaruhi keadaan stres oksidatif dan kadar antioksidan dalam tubuh.

\section{SIMPULAN}

Hasil penelitian ini menunjukkan koefisien korelasi negatif antara kadar SOD dan MDA jaringan keratosis seboroik yang artinya semakin rendah kadar SOD maka semakin tinggi kadar MDA pada jaringan keratosis seboroik. Penelitian lebih lanjut yang dapat dilakukan adalah membandingkan kadar SOD jaringan dan kadar MDA jaringan dengan kadar SOD serum dan kadar MDA serum pada pasien KS. Saran penelitian selanjutnya adalah membandingkan kadar SOD dan MDA jaringan pada lesi KS dan kulit sehat pasien KS.

\section{DAFTAR PUSTAKA}

1. Thomas VD, Snavely NR, Lee KK, Swanson NA. Benign Epithelial Tumors, Hamartomas, and Hyperplasias. Dalam: Goldsmith LA, Katz SI, Gilchrest BA, Paller AS, Leffel DJ, Wolff K, penyunting. Fitzpatrick's dermatology in general medicine. Edisi ke-8. New York: McGraw-Hill Companies; 2012.h.1319-22.

2. Smith dan Leggat. Prevalence of skin disease among the elderly in different clinical environments. Australas J Ageing. 2005;24:71-6.

3. Rinnerthaler M, Bischof J, Streubel MK, Trost A, Richter K. Oxidative stress in aging human skin. Biomolecules. 2015;5:54589.

4. Pandel R, Poljšak B, Godic A, Dahmane R. Skin photoaging and the role of antioxidants in its prevention. ISRN Dermatol. 2013;(930164):1-11.

5. Robbins D dan Zhao Y. The role of manganese superoxide dismutase in skin cancer. Enzyme Res. 2011;(409295):1-7.

6. Treiber N, Maity P, Singh K, Ferchiu F, Wlaschek M, Kochanek $\mathrm{KS}$. The role of manganese superoxide dismutase in skin aging. Dermato-Endocrinol. 2012;4: 232-5.

7. Nindya Sari AA. Kadar malondialdehid serum berkorelasi positif dengan melasma area and severity index. [Tesis]. Denpasar: Fakultas Kedokteran Universitas Udayana; 2014.

8. Jebor MA, Abood MR, Lilo RA. Biochemical changes in patients with benign prostate hyperplasia. J Univ Babylon. 2014;22:260511.

9. Ahmed SN. Alteration in serum 5'nucleitidase and malondialdehyde in breast tumors. Int $\mathrm{J}$ of Technic Res and Applications. 2015;3:170-3.

10. Bitla AR, Reddy EP, Sambasivaih K, Suchitra MM, Reddy VS, Rao PV. Evaluation of plasma malondialdehyde as a biomarker in patients with carcinoma of stomach. Biomed Res. 2011;22:638.

11. Dahlan S. Besar sampel dan cara pengambilan sampel dalam penelitian kedokteran dan kesehatan. Jakarta: Penerbit Salemba Medika; 2010.

12. Gill D, Dorevitch A, Marks R. The prevalence of seborrheic keratoses in people aged 15 to 30 years. Is the term senile keratosis redundant? Arch Dermatol. 2000;136:759-62.

13. Winarsi H, Wijayanti SPM, Purwanto A. Aktivitas enzim superoksida dismutase, katalase, dan glutation peroksidase wanita penderita sindrom metabolik. Majalah Kedokteran Bandung.2012;44:7-12.

14. Banerjee S. Seborrhoeic keratosis: bilaterally symmetrical linear verrucous lesions in inguinal folds, an unusual presentation. J Pakistan Assoc Dermatol. 2012;22:73-5.

15. Yaar M and Gilcherst B.A. Photoageing; Mechanism, prevention and Therapy. J Compilatotion-Brit J Dermatol. 2007;157:874-7.

16. Hafner C, Hartmann A, van Oers JM, Stoehr R, Zwarthoff EC, Hofstaedter F, dkk. FGFR3 mutations in seborrheic keratoses are already present in flat lesions and associated with age and localization. Mod Pathol. 2007;20:895-903.

17. Sujarweni V. Statistik Untuk Kesehatan. Yogyakarta: Penerbit Gava Medika; 2015.

18. Ayala A, Munoz MF, Arguelles S. Lipid peroxidation: production, metabolism, and signaling mechanisms of malondialdehyde and 4-hydroxy-2-nonenal. Oxid Med Cell Longev. 2014;(360438):131 .

19. Saeed dan Salmo. Epidermal growth factor receptor expression in mice skin upon ultraviolet B exposure - Seborrheic keratosis as a coincidental and unique finding. Adv Biomed Res. 2012;1:19.

20. Bickers dan Athar. Oxidative stress in the pathogenesis of skin disease. J Invest Dermatol. 2006;126:2565-75. 